\title{
Selection of 80 newly isolated autochthonous yeast strains from the Tikveš region of Macedonia and their impact on the quality of red wines produced from Vranec and Cabernet Sauvignon grape varieties
}

\author{
Fidanka Ilieva $^{\mathrm{a}, \mathrm{b}}$, Sanja Kostadinović Veličkovska ${ }^{\mathrm{b}, *}$, Violeta Dimovska $^{\mathrm{b}}$, Hamed Mirhosseini ${ }^{\mathrm{c}}$, \\ Hristo Spasov ${ }^{a}$ \\ a Department of Wine and Beer Technology, University of Food Technologies, Marica 26, Plovdiv, Bulgaria \\ ${ }^{\mathrm{b}}$ Faculty of Agriculture, University “Goce Delčev”, Krste Misirkov bb, 2000 Štip, Macedonia \\ ${ }^{\mathrm{c}}$ Department of Food Technology, Faculty of Food Science and Technology, Universiti Putra Selangor, Malaysia
}

\section{A R T I C L E I N F O}

\section{Article history:}

Received 24 January 2016

Received in revised form 12 August 2016

Accepted 17 August 2016

Available online 18 August 2016

\section{Keywords:}

Yeast diversity

Strain biotyping

Vranec wines

Cabernet Sauvignon wines

Monomeric anthocyanins

Phenolic compounds

\begin{abstract}
A B S T R A C T
The main objectives of this study were to (i) isolate newly autochthonous yeast strains from the Tikveš region of Macedonia and (ii) test their impact on the quality of red wines from Vranec and Cabernet Sauvignon grape varieties. The newly isolated yeast strains were obtained by spontaneous fermentation of grape must from Vranec and Cabernet Sauvignon varieties collected from ten different micro-regions in Macedonia. The grapevines from both varieties grown in "Barovo" micro-region were the richest sources of yeast strains. In addition, the molecular identification and typing of strains were also carried out. The monomeric anthocyanins, polyphenolic content and other oenochemical characteristics of the wines were also compared with the wines from commercial yeast strain "SiHa". The Vranec wine from yeast strain F-8 and Cabernet Sauvignon wine from yeast strain F-20 had significantly $(p<0.05)$ higher concentrations of monomeric anthocyanins and total phenolic compounds than other wines.
\end{abstract}

( 2016 Elsevier Ltd. All rights reserved.

\section{Introduction}

Domestication of wine yeast, while inadvertent until recent decades, has generated strains that differ considerably from "wild" S. cerevisiae strains. Inoculations of "wild" S. cerevisiae yeasts can influence the process of fermentation and greatly affect the quality of the wine. Isolating strains from successful fermentations for inoculation in subsequent vintages was being practiced during winemaking in order to avoid unwanted malolactic or acetic fermentation. Largely, the specifics and the most important quality characteristics of the wine are due to the natural microflora of the grape of the viticulture region. Bokulich, Thorngate, Richardson, and Mills (2014) proposed several promising strategies for improving grape and wine quality of individual varieties regarding the region, climate, and microbial patterns. The yeast ecology of sweet, botrytized wine fermentations from two individual vintages was investigated by new TRFLP approach for identification and discrimination of 121 yeast strains from 24 genera and 72 species (Bokulich, Hwang, Liu, Boundy-Mills, \& Mills, 2012).

\footnotetext{
* Corresponding author.

E-mail address: sanja.kostadinovik@ugd.edu.mk (S. Kostadinović Veličkovska).
}

As reported by Capece et al. (2010), two Nero d'Avola indigenous strains expressed completely different strain behavior after inoculation in the same must divided into two different tanks because of different ability to dominate the natural microflora present in the grape must. The low strain implantation can be due to the strong competition between wild yeasts and starter cultures and during alcoholic fermentation selected yeast strains cannot predominate the natural microflora during the whole process (Capece et al., 2010). The effect of different aging techniques on the polysaccharides, phenolic composition and sensory characteristics of Syrah red wines fermented using two different HPS and FERM yeast strains was studied (Del Barrio-Galán, MedelMarabolí, \& Peña-Neira, 2015). HPS yeast strain released a higher amount of low-molecular-weight polysaccharides during alcoholic fermentation than the FERM yeast strain. The group of Del BarrioGalán indicated the possible interaction between polysaccharides released from the HPS yeast strain and phenolic compounds in the wine. Consequently, wines produced by HPS strain had lower phenolic compounds than those produced by the FERM yeast strain. Furthermore, the study of the effect of different Saccharomyces cerevisiae yeasts on the level of stilbenes in Vranec wines proved that the wines produced by French yeast "Levuline CHP" had higher level of resveratrol than the wines from same 
grape variety produced by Macedonian yeast "Vinalco" (Kostadinović et al., 2012).

The effect of three different Saccharomyces cerevisiae yeasts (1EV, 2EV and 7EV) on the level of anthocyanins, pyranoanthocyanins and non-anthocyanins phenolic compounds in red wines produced by two grape varieties Tempranillo and Cabernet Sauvignon showed that anthocyanins and especially diglycosides were compounds the most affected by the type of yeast strain (Monagas, Goméz-Cordovéz, \& Bartolomé, 2007). Furthermore, the absorption of anthocyanins on the cell walls of the yeasts was influenced by their polarity and structural conformation (Morata et al., 2016). The effect of quantity of commercial strains during spontaneous fermentation of wines produced from grapevines from Mendoza region in Argentina reported by Mercado, Dalcero, Masuelli, and Combina (2007). Isolation and identification of 240 yeast Saccharomyces strain from the spontaneous fermentation of must from the region of La Mancha, Spain resulted in 21 different molecular profiles and micro vinification of the adequate yeasts for implantation and production of high-quality wines (Ortiz, Barrajón, Baffi, Arévalo-Villena, \& Briones, 2013). Furthermore, $S$. cerevisiae strains selected from the indigenous population of domestic winemaking enable the alcoholic fermentation to proceed more effectively in comparison with commercial yeast strains (Settanni, Sannino, Francesca, Guarcello, \& Moschetti, 2012). Among 26 Saccharomyces strains isolated from "Moscato di Saracena" wine from Calabria region in Italy, the autochthonous yeast strain M3-5 was more appropriate for fermentation than commercial strains (Aponte \& Blaiotta, 2016).

In the current study, the wider range of micro-regions from which grape samples were selected, will increase the probability of isolating wine yeasts with different properties, and that will, in turn, increase the opportunities for selection of specific and varietal local strains. Therefore, the present work represents the first approach to spontaneous fermentation Saccharomyces population dynamics in Tikveš region, the most important vinicultural region in Macedonia that has never been characterized before. Our previous report (Ilieva, Kostadinović Veličkovska, Dimovska, \& Spasov, 2016) indicated third-stage selected yeast strain F-78 as the best strain for alcoholic fermentation of Vranec wines. In the present study, the isolation of 80 yeast strains from spontaneously fermented grape must from 10 different micro-regions of Tikveš vinicultural region was applied and the fermentation activity of the yeast was studied. After the first and second stage selection, the molecular identification and typing of the most appropriate 10 yeasts were carried out. Finally, the effect of the 10 -second stage selected strains on the oenochemical parameters, monomeric anthocyanins and total phenolic compounds of wines produced from two grape varieties Vranec and Cabernet Sauvignon was investigated. To the best of our knowledge, no similar report has been published regarding the isolation of a wide range of autochthonous yeast strains from the Tikveš region and their application in red wines from Vranec and Cabernet Sauvignon grape varieties.

\section{Materials and methods}

\subsection{Grapes from Vranec and Cabernet Sauvignon grape variety for spontaneous fermentation}

A spontaneous fermentation of seven different lots of Vranec grapes and three different lots of Cabernet Sauvignon grapes from different micro-regions from Tikveš region was held in "Popova Kula” vinery, Demir Kapija (Table 1). From each grape variety, $150 \mathrm{~kg}$ samples were collected. The grapes from Cabernet Sauvignon grape variety were harvested at optimal maturity. The sugar content was in the range of $21-24 \%$, acidity $5.3-6.4 \mathrm{~g} / \mathrm{L}$ and $\mathrm{pH}$ ranged from 3.32 to 3.45 . The data for Vranec grape variety were reported by Ilieva et al. (2016).

\subsection{Spontaneous fermentation of Vranec and Cabernet Sauvignon grape varieties from "Tikveš" region}

A spontaneous fermentation of the must from three different lots of Cabernet Sauvignon grapes from "Barovo", "Kavadarci" and "Ljubash" micro-regions was held from the harvest 2010. Regarding the Vranec grape variety, the lots from seven micro regions are presented in Table 1 . The wines obtained by spontaneous fermentation of additional three lots from this grape variety were not used for isolation of yeast strains. Table 1 shows the alcohol content, residual sugars, $\mathrm{pH}$, titratable and volatile acids, monomeric anthocyanins and color intensity (IC) of the wines from differently fermented grape must. The procedure of isolation of pure culture of yeast strains and three stage selection were established by Ilieva et al. (2016).

\subsection{Determination of oenochemical parameters in trial wines}

Determination of the amount of alcohol was performed ebuliometrically with Dujardin - Salleron ebuliometer and for determination of reducing sugars the Schoorle method was used. Determination of titratable and volatile acidity of trial wines was performed by the previous method (Boulton, 1980). The color intensity (IC) was measured spectrophotometrically at $420 \mathrm{~nm}$ (yellow color), $520 \mathrm{~nm}$ (red color), $620 \mathrm{~nm}$ (blue color) by UV spectrophotometer Shimadzu 1800, Shimadzu corporation, Kyoto, Japan. Determination of monomeric anthocyanins and total phenolic method was performed by the colorimetric method (Singleton \& Rossi, 1965).

\subsection{Molecular identification and typing of newly isolated yeast strains}

For molecular identification and typing of seven strains of the species Saccharomyces cerevisiae, PCR- $\Delta$ multiplication of the DNA fragments was applied. In this study, the visualization of the result was made by gel-electrophorese (Legras \& Karst, 2003; Ness, Kowenz, Casini, Graf, \& Leutz, 1993). The reaction mixture used for PCR with reaction buffer contained: Tris- $\mathrm{HCl}(10 \mathrm{mM})$, $\mathrm{KCl}(50 \mathrm{mM})$ and $\operatorname{Triton}^{\circledR} \mathrm{X}-100(0.1 \% \mathrm{v} / \mathrm{v}), \mathrm{MgCl}_{2}$ (1.25 mM), primers $(0.83 \mu \mathrm{mol})$, deoxyribonucleotides: dATP, dTTP, dCTP et dGTP $(160 \mu \mathrm{M}$ each $)$ and DNA polymerase (0.042 U. $\mu \mathrm{L}-1)$. For the analyses of the inter- $\delta$ region, the primer pairs $\delta 12$ (TCAACAATGGAATCCCAAC) and $\delta 21$ (CATCTTAACACCGTATATGA) by sequence $\left(5^{\prime} \rightarrow 3^{\prime}\right)$ was used for PCR amplification. The amplification of $\delta$ region was performed directly from the colony, without previous DNA extraction, by increasing the time and the temperature of initial denaturation. After initial denaturation at $95{ }^{\circ} \mathrm{C}$ for $10 \mathrm{~min}$, the reaction mixture was cycled 35 times using by following program: $30 \mathrm{~s}$. denaturation at $95^{\circ} \mathrm{C}, 30 \mathrm{~s}$. primer annealing at $46^{\circ} \mathrm{C}$ and $90 \mathrm{~s}$. primer extension at $72{ }^{\circ} \mathrm{C}$ following by $10 \mathrm{~min}$. The final extension at $72{ }^{\circ} \mathrm{C}$. A microfermentation trials were performed in order to detect the weight loss stemming from $\mathrm{CO}_{2}$ releasing from the system. The glass bottles of $330 \mathrm{~mL}$ volume were poured by $150 \mathrm{~mL}$ must with the sugar concentration of $222 \mathrm{~g} / \mathrm{L}$, titratable acidity $4.1 \mathrm{~g} / \mathrm{L}$, the $\mathrm{pH}$ value of $3.52 \%$ and $3 \%$ inoculation culture. Fermentation was considered when no weight loss was any longer recorded within $24 \mathrm{~h}$. Fermentation rate was expressed as grams of $\mathrm{CO}_{2}$ produced by $100 \mathrm{~g}$ of must during the first $72 \mathrm{~h}$ of fermentation (Rinaldi, Blaiotta, Aponte, \& Luigi Moio, 2016). Each trial was performed in duplicate. 
Table 1

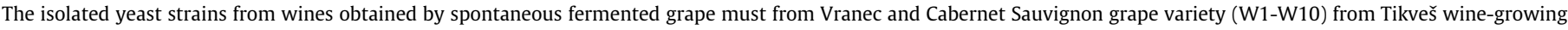
region.

\begin{tabular}{|c|c|c|c|c|c|c|c|c|c|}
\hline Wines & $\begin{array}{l}\text { The variety of grapes and } \\
\text { micro regions }\end{array}$ & $\begin{array}{l}\text { Alcohol } \\
\text { content } \%\end{array}$ & $\mathrm{pH}$ & $\begin{array}{l}\text { Titratable } \\
\text { acidity }(\mathrm{g} / \mathrm{L})\end{array}$ & $\begin{array}{l}\text { Sugar } \\
\text { content (\%) }\end{array}$ & $\begin{array}{l}\text { Volatile } \\
\text { acidity (g/L) }\end{array}$ & IC & $\begin{array}{l}\text { Monomeric } \\
\text { anthocyanins }\end{array}$ & Isolates code \\
\hline W1 & Vranec "Belgrade" & $12.5 \pm 0.8^{\mathrm{b}}$ & $3.43 \pm 0.01^{\mathrm{c}}$ & $6.5 \pm 0.3^{\mathrm{d}}$ & $0.96 \pm 0.12^{\mathrm{e}}$ & $0.39 \pm 0.05^{\mathrm{d}}$ & $16.7 \pm 0.33^{c}$ & $678 \pm 10^{c}$ & $\begin{array}{l}\text { F1-F5; F69- } \\
\text { F71 }\end{array}$ \\
\hline W2 & Vranec "Barovo" & $13.3 \pm 0.4^{\mathrm{a}}$ & $3.71 \pm 0.33^{\mathrm{a}}$ & $6.0 \pm 0.6^{\mathrm{e}}$ & $3.80 \pm 0.28^{\mathrm{b}}$ & $0.26 \pm 0.03^{e}$ & $21.8 \pm 2.21^{\mathrm{a}}$ & $724 \pm 4^{\mathrm{ab}}$ & $\begin{array}{l}\text { F6-F15; } \\
\text { F73-F78 }\end{array}$ \\
\hline W3 & Vranec "Gornichkite" & $13.0 \pm 0.1^{\mathrm{ab}}$ & $3.58 \pm 0.09^{b}$ & $6.2 \pm 1.1^{\mathrm{d}}$ & $6.30 \pm 0.66^{\mathrm{a}}$ & $0.25 \pm 0.09^{\mathrm{e}}$ & $21.1 \pm 1.41^{\mathrm{a}}$ & $733 \pm 4^{\mathrm{ab}}$ & F61-F64 \\
\hline W4 & Vranec "Bunishte" & $13.8 \pm 0.3^{\mathrm{a}}$ & $3.72 \pm 0.19^{\mathrm{a}}$ & $7.0 \pm 0.1^{\mathrm{c}}$ & $0.92 \pm 0.11^{\mathrm{e}}$ & $0.66 \pm 0.11^{\mathrm{a}}$ & $15.4 \pm 1.44^{\mathrm{d}}$ & $688 \pm 4^{c}$ & $\begin{array}{l}\text { F36-F40; } \\
\text { F65-F68 }\end{array}$ \\
\hline W5 & Vranec "Krushi” & $13.4 \pm 0.2^{\mathrm{a}}$ & $3.36 \pm 0.12^{c}$ & $7.4 \pm 0.3^{\mathrm{b}}$ & $0.46 \pm 0.12^{f}$ & $0.30 \pm 0.04^{\mathrm{de}}$ & $21.0 \pm 1.37^{\mathrm{a}}$ & $704 \pm 6^{\mathrm{b}}$ & F46-F50 \\
\hline W6 & Vranec “Beli Kamenja” & $13.5 \pm 0.2^{\mathrm{a}}$ & $3.63 \pm 0.44^{\mathrm{b}}$ & $6.2 \pm 1.0^{\mathrm{d}}$ & $3.00 \pm 0.21^{\mathrm{bc}}$ & $0.39 \pm 0.07^{d}$ & $21.8 \pm 0.99^{a}$ & $796 \pm 3^{a}$ & $\begin{array}{l}\text { F29-F32; } \\
\text { F51-F55 }\end{array}$ \\
\hline W7 & Vranec "Roviti Kamen" & $12.9 \pm 0.1^{\mathrm{b}}$ & $3.50 \pm 0.09^{b}$ & $8.0 \pm 1.0^{\mathrm{a}}$ & $0.99 \pm 0.11^{\mathrm{e}}$ & $0.45 \pm 0.09^{c}$ & $17.8 \pm 0.88^{\mathrm{b}}$ & $650 \pm 4^{c}$ & $\begin{array}{l}\text { F33-F35; } \\
\text { F56-F60 }\end{array}$ \\
\hline W8 & $\begin{array}{l}\text { Cabernet Sauvignon } \\
\text { "Barovo" }\end{array}$ & $12.2 \pm 0.8^{\mathrm{b}}$ & $3.35 \pm 0.23^{c}$ & $5.8 \pm 0.8^{\mathrm{e}}$ & $2.30 \pm 0.41^{\mathrm{c}}$ & $0.48 \pm 0.04^{\mathrm{c}}$ & $16.5 \pm 0.64^{c}$ & $381 \pm 5^{e}$ & $\begin{array}{l}\text { F16-F25; } \\
\text { F72; F79 }\end{array}$ \\
\hline W9 & $\begin{array}{l}\text { Cabernet Sauvignon } \\
\text { "Kavadarci" }\end{array}$ & $13.2 \pm 0.4^{\mathrm{a}}$ & $3.30 \pm 0.14^{\mathrm{d}}$ & $5.7 \pm 1.0^{\mathrm{e}}$ & $2.80 \pm 0.09^{c}$ & $0.52 \pm 0.12^{\mathrm{b}}$ & $17.8 \pm 2.21^{\mathrm{b}}$ & $410 \pm 7^{d}$ & $\begin{array}{l}\text { F26-F28; } \\
\text { F80 }\end{array}$ \\
\hline W10 & $\begin{array}{l}\text { Cabernet Sauvignon } \\
\text { "Ljubash" }\end{array}$ & $12.7 \pm 0.5^{\mathrm{b}}$ & $3.28 \pm 0.65^{\mathrm{d}}$ & $6.0 \pm 0.5^{\mathrm{e}}$ & $1.45 \pm 0.13^{\mathrm{d}}$ & $0.50 \pm 0.08^{\mathrm{b}, \mathrm{c}}$ & $17.6 \pm 1.99^{\mathrm{b}}$ & $396 \pm 4^{\mathrm{e}}$ & F41-F45 \\
\hline
\end{tabular}

The results were expressed in $\mathrm{mg} / \mathrm{L} \pm \mathrm{SD}$ of two replicates. The different letters means significant differences among results. ${ }^{\mathrm{a}-\mathrm{f}}$ Significant difference at $\mathrm{p}<0.05$.

\subsection{Application of 10-yeast strains from second stage selection in the wine-making from Vranec and Cabernet Sauvignon grape varieties}

The grapes from Vranec and Cabernet Sauvignon grape varieties were equally allocated to the different lots. The berries were exuded from the cluster by hand and crushed by hand crusher. After crushing, the must was put in plastic containers of $20 \mathrm{~L}$ and added $20 \mathrm{mg} /$ $\mathrm{kg} \mathrm{SO}$. Two hours after addition of $\mathrm{SO}_{2}$, the must was inoculated with the previously cultivated liquid cultures from the secondstage selected strains in sterilized grape juice. The inoculum from Vranec grape variety was prepared by addition of $3 \%$ of inoculation culture in the must with $21.2 \%$ sugar content, titratable acidity $6.3 \mathrm{~g} / \mathrm{L}$ and $\mathrm{pH}$ 3.41. The inoculum from Cabernet Sauvignon grape variety contained $3 \%$ of inoculated culture in the must with $20.5 \%$ sugar content, titratable acidity $7.3 \mathrm{~g} / \mathrm{L}$ and $\mathrm{pH} 3.45$. All experiments were performed in musts which contained natural microflora. Since the domination of inoculated strains over natural microbiota was not object of this study, results reported in Tables 2 and 3 were directly related to inoculated cultures. Furthermore, 7 trial lots from Vranec grape and 3 trial lots from Cabernet Sauvignon grape with the selected yeast strains from the second stage and one control lot for each variety, which was inoculated with commercial strain $\mathrm{SiHa}$, were found. The alcoholic fermentation of the trials was performed in duplicate and held on $23-25^{\circ} \mathrm{C}$.

\subsection{Statistical analysis}

A one-way ANOVA was used to examine the impact of every selected yeast strains on the level of monomeric anthocyanins, total phenolic compounds, reducing sugars, $\mathrm{pH}$, volatile and titratable acids, residual and total $\mathrm{SO}_{2}$. The level of significance in differences between anthocyanin content and total phenolic content was determined by $5 \%$ by a one-way ANOVA using Tukey's test. SPSS v.16.0 software (IBM corporation, USA) was used for the creation of the treatments and further data analysis.

\section{Results and discussion}

\subsection{Isolation of yeast strains from wines from spontaneous fermentation of Vranec and Cabernet Sauvignon grape variety}

In the present study, $80 \mathrm{~S}$. cerevisiae strains were isolated from wines obtained by spontaneous fermentation of must from Vranec and Cabernet Sauvignon grapes from Tikveš viticulture region. During spontaneous fermentation of the must, the temperature range was between $25^{\circ} \mathrm{C}$ and $28^{\circ} \mathrm{C}$. At the end of alcoholic fermentation, the oenochemical parameters of experimental wines were measured. The highest alcohol content was observed in Vranec wine W4 $(13.8 \pm 0.3 \%)$ and the lowest quantity was detected in Cabernet Sauvignon wine W8 $(12.2 \pm 0.8 \%)$. The $\mathrm{pH}$ of all 10 wines ranged from $3.28 \pm 0.65$ to $3.72 \pm 0.19$. The wine W3 had the highest sugar content $(6.30 \pm 0.66 \%)$; while the wine W5 showed the lowest sugar content $(0.46 \pm 0.12 \%)$ among all 10 wines. The wine W6 from Vranec grape variety from "Beli Kamenja" micro-region had the highest concentration of monomeric anthocyanins and the highest intensity of the color (IC). On the other hand, the wine W8 from Cabernet Sauvignon grape variety from "Barovo" microregion showed the lowest level of monomeric anthocyanins and the lowest IC among all samples.

As shown in Table 1 and 69 yeast strains were isolated from Vranec wines (W1 - W7) and 21 yeast strains were isolated from Cabernet Sauvignon wines (W8 - W10). The wine W2 produced from Vranec grapes from "Barovo" micro-region was the source of 16 yeast strains while wine W3 produced from the same grape variety from "Gornichkite" micro-region was the source of 4 yeast strains. Given that, wine W8 produced from Cabernet Sauvignon grapes from the same micro region "Barovo" was the source of 12 new yeast strains. It was concluded that grapevines from both varieties grown from "Barovo" micro-region were the richest sources of yeast strains.

\subsection{Fermentative activity of 80 newly isolated yeast strains from wines}

The new yeast strains (F1-F80) isolated from wines obtained by spontaneous fermented must (W1-W10) demonstrated different dynamic of alcoholic fermentation and different content of dry matter. Generally speaking, the alcoholic fermentation caused by most of the yeast strains had similar course, starting at the 24th hour and ending between the 6th and 10th day. Within the 1st day, $4-6 \%$ of the sugars were already fermented with the slow decrease at the 2nd day and increase again during the 3rd day of alcoholic fermentation.

Regarding the dynamics of alcoholic fermentation of experimental wines, the 80 newly isolated yeast strains were categorized into four groups: the group A consists of yeast strains 
Table 2

Oenochemical parameters of experimental wines from Vranec and Cabernet Sauvignon grape variety produced by ten second stage selected yeast strains.

\begin{tabular}{|c|c|c|c|c|c|c|c|c|}
\hline & Strain & Alcohol (\%) & Sugar content $(\mathrm{g} / \mathrm{L})$ & Titratable acidity $(\mathrm{g} / \mathrm{L})$ & Volatile acidity $(\mathrm{g} / \mathrm{L})$ & $\mathrm{pH}$ & Free $\mathrm{SO}_{2}(\mathrm{mg} / \mathrm{L})$ & Total $\mathrm{SO}_{2}(\mathrm{mg} / \mathrm{L})$ \\
\hline \multicolumn{9}{|c|}{ Oenochemical parameters of the Vranec wines } \\
\hline V1 & $\mathrm{F}-4$ & $14.6 \pm 1.0^{\mathrm{a}}$ & $1.45 \pm 0.23^{\mathrm{c}}$ & $6.0 \pm 0.9^{\mathrm{a}}$ & $0.30 \pm 0.01^{\mathrm{ab}}$ & $3.43 \pm 0.44^{\mathrm{b}}$ & $48.0 \pm 2.6^{\mathrm{a}}$ & $81.6 \pm 3.4^{\mathrm{a}}$ \\
\hline $\mathrm{V} 2$ & $\mathrm{~F}-8$ & $14.2 \pm 1.1^{\mathrm{ab}}$ & $2.40 \pm 0.34^{\mathrm{b}}$ & $5.7 \pm 1.0^{\mathrm{b}}$ & $0.32 \pm 0.05^{\mathrm{ab}}$ & $3.39 \pm 0.58^{\mathrm{b}}$ & $35.2 \pm 1.4^{\mathrm{bc}}$ & $48.0 \pm 3.0^{c}$ \\
\hline V3 & $\mathrm{F}-17$ & $14.4 \pm 0.2^{\mathrm{ab}}$ & $1.00 \pm 0.12^{\mathrm{d}}$ & $5.0 \pm 0.5^{c}$ & $0.32 \pm 0.09^{\mathrm{ab}}$ & $3.53 \pm 0.72^{\mathrm{ab}}$ & $38.4 \pm 3.1^{\mathrm{b}}$ & $55.2 \pm 4.1^{\mathrm{b}}$ \\
\hline V4 & $\mathrm{F}-20$ & $14.6 \pm 0.5^{\mathrm{a}}$ & $1.60 \pm 0.09^{c}$ & $5.0 \pm 0.2^{c}$ & $0.39 \pm 0.02^{\mathrm{a}}$ & $3.56 \pm 0.31^{\mathrm{ab}}$ & $31.2 \pm 5.0^{c}$ & $51.2 \pm 5.1^{\mathrm{b}}$ \\
\hline V5 & F-39 & $14.4 \pm 1.2^{\mathrm{ab}}$ & $1.45 \pm 0.17^{\mathrm{c}}$ & $6.1 \pm 0.3^{a}$ & $0.36 \pm 0.08^{\mathrm{a}}$ & $3.44 \pm 0.69^{\mathrm{b}}$ & $34.4 \pm 4.0^{\mathrm{bc}}$ & $48.8 \pm 2.2^{\mathrm{c}}$ \\
\hline V6 & $\mathrm{F}-42$ & $14.5 \pm 1.0^{\mathrm{a}}$ & $1.90 \pm 0.21^{\mathrm{c}}$ & $5.4 \pm 0.6^{\mathrm{b}}$ & $0.36 \pm 0.11^{\mathrm{a}}$ & $3.49 \pm 0.55^{\mathrm{ab}}$ & $39.2 \pm 2.0^{\mathrm{b}}$ & $55.0 \pm 2.8^{\mathrm{b}}$ \\
\hline V7 & $\mathrm{F}-46$ & $14.4 \pm 1.0^{\mathrm{ab}}$ & $2.90 \pm 0.04^{b}$ & $6.5 \pm 0.2^{\mathrm{a}}$ & $0.30 \pm 0.04^{\mathrm{ab}}$ & $3.37 \pm 0.91^{\mathrm{b}}$ & $35.2 \pm 3.1^{b c}$ & $46.4 \pm 3.1^{\mathrm{c}}$ \\
\hline V8 & F-57 & $14.0 \pm 0.5^{\mathrm{b}}$ & $0.80 \pm 0.05^{\mathrm{d}}$ & $5.5 \pm 0.3^{b}$ & $0.36 \pm 0.02^{\mathrm{ab}}$ & $3.40 \pm 0.66^{\mathrm{b}}$ & $36.8 \pm 3.0^{\mathrm{bc}}$ & $47.2 \pm 3.5^{c}$ \\
\hline V9 & F-70 & $14.0 \pm 0.2^{\mathrm{b}}$ & $1.30 \pm 0.11^{\mathrm{c}}$ & $5.6 \pm 0.2^{\mathrm{b}}$ & $0.30 \pm 0.03^{\mathrm{ab}}$ & $3.46 \pm 0.51^{\mathrm{ab}}$ & $38.4 \pm 4.1^{\mathrm{b}}$ & $52.0 \pm 4.2^{\mathrm{b}}$ \\
\hline V10 & F-78 & $14.5 \pm 0.4^{\mathrm{a}}$ & $3.20 \pm 0.21^{\mathrm{a}}$ & $5.8 \pm 1.0^{\mathrm{b}}$ & $0.30 \pm 0.09^{\mathrm{ab}}$ & $3.41 \pm 0.21^{\mathrm{b}}$ & $25.6 \pm 1.0^{\mathrm{d}}$ & $52.8 \pm 2.4^{\mathrm{b}}$ \\
\hline \multirow[t]{2}{*}{ V11 } & $\mathrm{SiHa}$ & $14.2 \pm 2.0^{\mathrm{ab}}$ & $2.60 \pm 0.17^{b}$ & $4.3 \pm 0.7^{\mathrm{c}}$ & $0.24 \pm 0.05^{\mathrm{b}}$ & $3.71 \pm 0.39^{\mathrm{a}}$ & $27.2 \pm 0.9^{d}$ & $45.6 \pm 3.1^{c}$ \\
\hline & Strain & Alcohol (\%) & Sugar content $(\mathrm{g} / \mathrm{L})$ & Titratable acidity (g/L) & Volatile acidity (g/L) & $\mathrm{pH}$ & Free $\mathrm{SO}_{2}(\mathrm{mg} / \mathrm{L})$ & Total $\mathrm{SO}_{2}(\mathrm{mg} / \mathrm{L})$ \\
\hline CS1 & $\mathrm{F}-4$ & $14.0 \pm 0.8^{b}$ & $2.61 \pm 0.11^{\mathrm{b}}$ & $6.6 \pm 0.2^{\mathrm{a}}$ & $0.24 \pm 0.02^{\mathrm{b}}$ & $3.55 \pm 0.17^{b}$ & $32.8 \pm 3.1^{\mathrm{b}}$ & $63.2 \pm 4.5^{c}$ \\
\hline CS2 & $\mathrm{F}-8$ & $13.9 \pm 0.2^{\mathrm{b}}$ & $2.93 \pm 0.27^{\mathrm{a}}$ & $5.3 \pm 0.2^{b}$ & $0.31 \pm 0.07^{\mathrm{a}}$ & $3.73 \pm 0.31^{\mathrm{a}}$ & $24.0 \pm 4.3^{c}$ & $36.8 \pm 2.9^{\mathrm{e}}$ \\
\hline CS3 & $\mathrm{F}-17$ & $14.0 \pm 0.5^{\mathrm{a}}$ & $2.62 \pm 0.29^{b}$ & $4.9 \pm 0.9^{c}$ & $0.30 \pm 0.11^{\mathrm{a}}$ & $3.81 \pm 0.43^{\mathrm{a}}$ & $36.0 \pm 1.1^{\mathrm{ab}}$ & $57.6 \pm 0.5^{\mathrm{d}}$ \\
\hline $\mathrm{CS} 4$ & $\mathrm{~F}-20$ & $13.8 \pm 1.2^{\mathrm{b}}$ & $2.92 \pm 0.19^{a}$ & $6.0 \pm 0.5^{\mathrm{a}}$ & $0.32 \pm 0.04^{\mathrm{a}}$ & $3.56 \pm 0.21^{b}$ & $40.8 \pm 0.9^{\mathrm{a}}$ & $84.0 \pm 0.2^{\mathrm{a}}$ \\
\hline CS5 & F-39 & $13.8 \pm 0.2^{\mathrm{b}}$ & $1.60 \pm 0.24^{c}$ & $5.5 \pm 1.0^{\mathrm{b}}$ & $0.27 \pm 0.09^{b}$ & $3.61 \pm 0.09^{\mathrm{a}}$ & $39.2 \pm 0.4^{\mathrm{a}}$ & $62.4 \pm 3.2 \mathrm{~cd}$ \\
\hline CS6 & $\mathrm{F}-42$ & $13.7 \pm 1.4^{\mathrm{b}}$ & $1.38 \pm 0.08^{c}$ & $5.4 \pm 0.7^{b}$ & $0.24 \pm 0.08^{b}$ & $3.66 \pm 0.38^{\mathrm{a}}$ & $32.0 \pm 0.6^{\mathrm{b}}$ & $55.2 \pm 2.4^{\mathrm{d}}$ \\
\hline CS7 & F-46 & $14.0 \pm 2.0^{\mathrm{a}}$ & $2.61 \pm 0.31^{b}$ & $6.6 \pm 0.5^{a}$ & $0.21 \pm 0.05^{c}$ & $3.55 \pm 0.63^{b}$ & $28.0 \pm 3.2^{c}$ & $52.0 \pm 1.8^{\mathrm{d}}$ \\
\hline CS8 & F-57 & $13.9 \pm 1.7^{\mathrm{b}}$ & $2.94 \pm 0.42^{\mathrm{a}}$ & $4.8 \pm 0.2^{\mathrm{c}}$ & $0.27 \pm 0.02^{\mathrm{b}}$ & $3.64 \pm 0.21^{\mathrm{a}}$ & $26.4 \pm 4.6^{\mathrm{c}}$ & $40.0 \pm 2.4^{\mathrm{e}}$ \\
\hline CS9 & F-70 & $14.0 \pm 1.3^{\mathrm{a}}$ & $2.28 \pm 0.31^{\mathrm{b}, \mathrm{c}}$ & $6.0 \pm 0.8^{b}$ & $0.30 \pm 0.04^{\mathrm{a}}$ & $3.65 \pm 0.77^{\mathrm{a}}$ & $28.8 \pm 1.2^{\mathrm{c}}$ & $58.4 \pm 3.1^{d}$ \\
\hline CS10 & F-78 & $14.1 \pm 1.7^{\mathrm{a}}$ & $2.63 \pm 0.65^{\mathrm{b}}$ & $5.4 \pm 0.1^{\mathrm{b}}$ & $0.33 \pm 0.01^{\mathrm{a}}$ & $3.59 \pm 0.84^{\mathrm{a}}$ & $32.8 \pm 0.8^{\mathrm{b}}$ & $56.0 \pm 0.8^{d}$ \\
\hline CS11 & $\mathrm{SiHa}$ & $13.5 \pm 2.0^{c}$ & $2.91 \pm 0.26^{\mathrm{a}}$ & $5.3 \pm 0.6^{\mathrm{b}}$ & $0.37 \pm 0.06^{\mathrm{a}}$ & $3.55 \pm 0.39^{b}$ & $36.8 \pm 0.4^{\mathrm{a}, \mathrm{b}}$ & $76.8 \pm 0.5^{\mathrm{b}}$ \\
\hline
\end{tabular}

The results were expressed in $\mathrm{mg} / \mathrm{L} \pm \mathrm{SD}$ of two replicates. The different letters means significant differences among results. ${ }^{\mathrm{a}-\mathrm{d}}$ Significant difference at $\mathrm{p}<0.05$.

Table 3

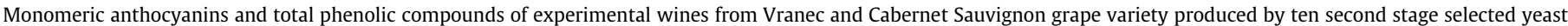
strains.

\begin{tabular}{|c|c|c|c|c|c|c|}
\hline $\begin{array}{l}\text { Yeast } \\
\text { strains }\end{array}$ & $\begin{array}{l}\text { Vranec } \\
\text { wines }\end{array}$ & $\begin{array}{l}\text { Monomeric anthocyanins } \\
(\mathrm{mg} / \mathrm{L})\end{array}$ & $\begin{array}{l}\text { Total phenolic compounds } \\
(\mathrm{mg} / \mathrm{L})\end{array}$ & $\begin{array}{l}\text { Cabernet Sauvignon } \\
\text { wines }\end{array}$ & $\begin{array}{l}\text { Monomeric anthocyanins } \\
(\mathrm{mg} / \mathrm{L})\end{array}$ & $\begin{array}{l}\text { Total phenolic compounds } \\
(\mathrm{mg} / \mathrm{L})\end{array}$ \\
\hline $\mathrm{F} 4$ & V1 & $521 \pm 43^{c}$ & $2601 \pm 14^{\mathrm{b}}$ & CS1 & $465 \pm 7^{\mathrm{bc}}$ & $2252 \pm 5^{e}$ \\
\hline F8 & V2 & $625 \pm 8^{a}$ & $2896 \pm 5^{\mathrm{a}}$ & $\mathrm{CS} 2$ & $417 \pm 7^{d}$ & $2495 \pm 8^{b}$ \\
\hline F17 & V3 & $429 \pm 6^{\mathrm{gh}}$ & $1993 \pm 13^{f}$ & CS3 & $386 \pm 7^{e}$ & $2464 \pm 7^{c}$ \\
\hline F20 & V4 & $463 \pm 14^{\mathrm{ef}}$ & $2029 \pm 22^{\mathrm{e}}$ & CS4 & $501 \pm 7^{a}$ & $2720 \pm 12^{\mathrm{a}}$ \\
\hline F39 & V5 & $491 \pm 12^{\text {cde }}$ & $2472 \pm 25^{c}$ & CS5 & $382 \pm 7^{e}$ & $2490 \pm 6^{b}$ \\
\hline F42 & V6 & $473 \pm 8^{\text {def }}$ & $2320 \pm 12^{\mathrm{d}}$ & CS6 & $470 \pm 3^{b}$ & $2482 \pm 2^{\mathrm{bc}}$ \\
\hline F46 & V7 & $583 \pm 6^{b}$ & $2815 \pm 22^{\mathrm{a}}$ & CS7 & $466 \pm 0^{\mathrm{bc}}$ & $2453 \pm 28^{c}$ \\
\hline F57 & V8 & $504 \pm 7 \mathrm{~cd}$ & $2480 \pm 7^{c}$ & CS8 & $474 \pm 6^{\mathrm{b}}$ & $2206 \pm 7^{f}$ \\
\hline F70 & V9 & $458 \pm 3^{\mathrm{fg}}$ & $2436 \pm 5^{c}$ & CS9 & $423 \pm 4^{\mathrm{d}}$ & $2393 \pm 10^{\mathrm{e}}$ \\
\hline F78 & V10 & $493 \pm 6^{\text {cde }}$ & $2506 \pm 8^{b}$ & CS10 & $453 \pm 6^{c}$ & $2433 \pm 33^{d}$ \\
\hline $\mathrm{SiHa}$ & V11 & $421 \pm 0^{\mathrm{h}}$ & $2487 \pm 9^{b}$ & CS11 & $354 \pm 4^{\mathrm{f}}$ & $1738 \pm 25^{g}$ \\
\hline
\end{tabular}

Concentrations were expressed in $\mathrm{mg} / \mathrm{L} \pm \mathrm{SD}$ of two replicates. The different letters means significant differences among results. ${ }^{\mathrm{a}-\mathrm{h}}$ Significant difference at $\mathrm{p}<0.05$.

with the quick start of alcoholic fermentation within 24th hours after inoculation and the most of the sugars were fermented in the next five days. The strains F-3, F-4, F-26, F-28, F-29, F-39, F-60, F-70, F-78 and F-80 belong to this group. The group B consist of yeast strains with the linear decline from 1 st till 4 th day of alcoholic fermentation. From 4th till 6th day some delay of fermentative activity was observed for yeast strains F-32, F-41, F-43, F-54. The isolated yeasts showed activity again from 6th until the 8th day of fermentation. During this period around $22-25 \%$ of the carbohydrates were assimilated, in comparison to the group above, where this percentage was in the range from $6 \%$ to $9 \%$. The Group C consists of yeast strains with the remarkable $\beta$-glucosidase activity which complete alcoholic fermentation in the first six days. During the first six days of alcoholic fermentation by yeast strains F-8, F-17 and F-57, the percentage of dry matter decreased from $23 \%$ to $6 \%$. The yeast strains F-24, F-53 and F-62 represent group D with the slow start in the first $24 \mathrm{~h}$. During the next stages of the fermentation, $\beta$-glucosidase activity was very low with slow sugars decreasing and prolonged the process, and in the case of yeast F-62, the alcoholic fermentation was not completed.
3.3. Fermentative activity of the first-stage selected 40 yeast strains: evaluation of the fermentation dynamics and efficiency and second stage selection

\subsubsection{The fermentation rate}

Within the first 24 hours most of the strains such F-4, F-11, F$17, \mathrm{~F}-42, \mathrm{~F}-57$, and $\mathrm{F}-78$ released $\mathrm{CO}_{2}$ in the range of $1-1.5 \mathrm{~g}$ which was approximately from 7 to $12 \%$ of the total quantity of released $\mathrm{CO}_{2}$. About fourteen strains as F-33, F-49 and F-58 were significantly slower in starting alcoholic fermentation and for the first 24 hours, they released less than $1 \mathrm{~g}$ of $\mathrm{CO}_{2}$ which was less than $3 \%$ of the total quantity of $\mathrm{CO}_{2}$. The yeast strain $\mathrm{F}-37$ demonstrated the fastest start and released $24 \%$ of the total quantity of $\mathrm{CO}_{2}$. After the 3rd day of alcoholic fermentation, almost $75 \%$ of the secondstage selected yeasts strains released between 4 and $6 \mathrm{~g} \mathrm{CO}_{2}$ which was about 30 and $45 \%$ of the total quantity of $\mathrm{CO}_{2}$. The maximum quantity of $\mathrm{CO}_{2}$ was released at this stage by the strains $\mathrm{F}-42$ and $\mathrm{F}$ 57 ( $6.50 \pm 0.09$ and $7.11 \pm 0.14 \mathrm{~g} \mathrm{CO}_{2}$ respectively). More than half of the 40 strains explored in this stage released around $85 \%$ of the total quantity of $\mathrm{CO}_{2}$ by the end of the 9th day of alcoholic fermentation and 6 strains released around 90\% of the total amount of 
$\mathrm{CO}_{2}$. The most typical strains from this group were $\mathrm{F}-4, \mathrm{~F}-8, \mathrm{~F}-42$ and F-57. There are also strains which showed inhibition such F-12, F-22 and F-58. At the end of the process, the maximum quantity of released gas was $13.4 \pm 0.9 \mathrm{~g}$ by yeast strain F-4 and the minimum quantity $10.9 \pm 1.0 \mathrm{~g}$ by yeast strain F-58. According to the findings reported by Ortiz et al. (2013), the proper fermentation velocity $\left(1.25 \mathrm{~g} \mathrm{CO}_{2} / \mathrm{L} / \mathrm{h}\right)$ was detected for strains obtained from spontaneously fermented wines from "La Mancha" region in Spain which was higher in comparison to fermentation rate of the most of isolated yeast strains from Tikveš region.

\subsubsection{The reducing sugar concentrations}

The reducing sugar concentrations were significantly different and indicated completing the alcoholic fermentation in various degrees. The concentrations vary between $2.28 \pm 0.12 \mathrm{~g} / \mathrm{L}$ (for strain F-46) and $23.52 \pm 0.22 \mathrm{~g} / \mathrm{L}$ (for strain F-58). The alcoholic fermentation was not completed in some experimental wines with residual sugars more than $10 \mathrm{~g} / \mathrm{L}$ produced by yeast strains $\mathrm{F}-22$, F-33, F-34 and F-48. The behavior of these yeasts can be related to the statement reported by Capece et al. (2010). They reported that the inoculation with selected starters does not always guarantee successful completion of alcoholic fermentation. Low implantation of the native yeast starters can result from unstable fermentation conditions (Capece et al., 2010). However, despite the fact that some of the selected yeast strains did not complete the alcoholic fermentation in experimental wines, the most of the studied strains succeeded in finishing the process and metabolized the sugars to less than $4 \mathrm{~g} / \mathrm{L}$. From this point of view, the most resistant were F-39, F-42, F-57, F-78 and F-70. These yeast strains are highly resistant to inhibitory factors, which gives us reason to suppose that in normal oxy-reduction conditions, the strains will finish alcoholic fermentation successfully. Ortiz et al. (2013) confirmed that almost $95 \%$ of isolated yeasts from spontaneously fermented wines from "La Mancha" region exhausted all sugars during the period of 15 days and successfully completed fermentation.

\subsubsection{The fermentation power}

Alcohol content in experimental wines generally corresponded to the quantity of metabolized sugar and vary from $11.15 \pm 0.17 \%$ $\mathrm{v} / \mathrm{v}$ for yeast strain $\mathrm{F}-22$ to $13.15 \pm 0.25 \% \mathrm{v} / \mathrm{v}$ for yeast strain F-78. Values of titratable acids in almost all samples vary in the range between $4.3 \pm 0.3 \mathrm{~g} / \mathrm{L}$ and $5.3 \pm 0.7 \mathrm{~g} / \mathrm{L}$. These values were equal or higher in comparison to the titratable acids in the grape juice. Consequently, the synthesis of acids predominated over their assimilation. High levels of titratable acids for the strains F-48 and F-49 almost double were observed in comparison to the acid in other experimental wines ( $7.6 \pm 0.8$ and $8.4 \pm 1.0 \mathrm{~g} / \mathrm{L}$ respectively). These strains could be interesting for fermentation of grapevines deficient in acids.

Volatile acids varied from $0.47 \pm 0.06$ to $0.80 \pm 0.17 \mathrm{~g} / \mathrm{L}$, expressed as acetic acid. This range is high for enological purposes but expected for experimental wines, produced in small volumes. The conversion coefficients, characterizing the transformation of sugars in ethanol, were calculated with values varied between 0.577 and 0.604 which indicated the good efficiency of studied yeasts. It was found that there are a lot of experimental strains, for which amount of alcohol was over $13 \% \mathrm{v} / \mathrm{v}$, the residual sugars were less than $4 \mathrm{~g} / \mathrm{L}$, consequently the fermentation process was entirely completed and the conversion coefficients were between 0.585 and 0.595 (F-4, F-42, F-57, F-70 and F-78). Other low effective yeast strains such F-25 and F-56 had lower coefficients ranging from 0.570 to 0.580 .

The second stage of selection was carried out based on the results obtained from fermentative activity, oenochemical composition analysis, and the conversion coefficients. The yeast strains selected on the second stage were mainly isolated from Vranec wines (7 strains), and less from Cabernet Sauvignon wines (3 strains). This was expected, considering the fact that Vranec is the typical grape variety from Macedonia and the use of the newly isolated local strains would show the specificity of regional Vranec wines (Ilieva et al., 2016). Considering the regions of isolation, five of the strains isolated during the second stage of selection were from "Barovo" and "Belgrade" micro-regions. This gives us reason to suppose that in these two micro-regions were greater quantity of local yeast populations with high activity, appropriate metabolism and effective transformation of carbohydrates.

\subsection{Molecular identification and typing of the second stage selected strains}

The amplification of inter-delta region is the most discriminative method for determination of genetic properties of wine yeast strains (Capece, Romaniello, Siesto, \& Romano, 2012). After observation of the specific PCR reaction for all the 7 strains, we can confirm that these cultures belong to the Saccharomyces cerevisiae species. Fig. 1 shows the DNA-profiles of the studied yeast strains. Five different profiles are presented below, describing the number and size of segments of DNA, which confirm that at least five different biotypes were presented among S. cerevisiae strains. Five segments were confirmed in commercial strain SiHa $(800,500,210,180$ and 130 base pairs), six segments for yeast strain F-78 (500, 400, 340, 180, 130 and 90 base pairs), seven segments for strain F-8 $(500,400,380,340,180,130$ and 90 base pairs), six segments for strain F-70 (500, 250, 210, 180, 130 and 90 base pairs), five segments for strain F-57 (800, 500, 210, 180 and 130 base pairs), six segments for strain F-42 (500, 250, 210 , 180,130 and 90 base pairs) and six segments for strain F-46 $(550,500,450,180,130$ and 90 base pairs). The analysis of identified DNA-profiles showed that strain $\mathrm{F}-57$ has a profile almost identical to the profile of control strain SiHa. Additionally, strains F-42 and F-70 had very similar profiles.

3.5. The effect of the 10 second-stage selected strains on oenochemical parameters of Vranec and Cabernet Sauvignon wines

Alcoholic fermentation of must from Vranec and Cabernet Sauvignon grape varieties from vintage 2011 by 10 yeast strains from the second-stage selection was performed. The alcoholic fermentation in all samples was similar by intensive decreasing of dry matter and finishing the process within 9 days. The fast start of alcoholic fermentation was typical for ten yeast strains. Within the first day, 5-6\% of the sugars were already fermented, after that the slow decrease was observed and after the 3rd day intensified again. With the exception of wine V10 produced by yeast strain $\mathrm{F}-78$, the residual sugars in all of the trials covered the dry wine limits bellow $3 \mathrm{~g} / \mathrm{L}$ (Table 2). That means all of the studied strains completed the alcoholic fermentation. The alcohol content varied in short limits from $13.5 \pm 2.0 \% \mathrm{v} / \mathrm{v}$ for Cabernet Sauvignon wine CS11 produced by commercial yeast strain SiHa and $14.1 \pm 1.7 \%$ $\mathrm{v} / \mathrm{v}$ for Cabernet Sauvignon wine CS10 produced by newly isolated yeast strain F-78. Regarding Vranec wines produced by yeast strains F-4, F-20, F-42 and F-78, the alcohol content was higher than $14.4 \% \mathrm{v} / \mathrm{v}$ which corresponds to the sugar content of this grape variety.

The conversion coefficients varied in the range from 0.575 to 0.596 and the highest was for strain F- Vranec wine V4 and the lowest was in CS11 wine produced by control strain SiHa. The titratable acid content was in expected ranges, a little higher for wines produced by yeast strains F-4, F-39 and F-46. The more intensive acid formation can be the result of different amount of lactic, succinic, citric and acetic acids presented in the grape must 


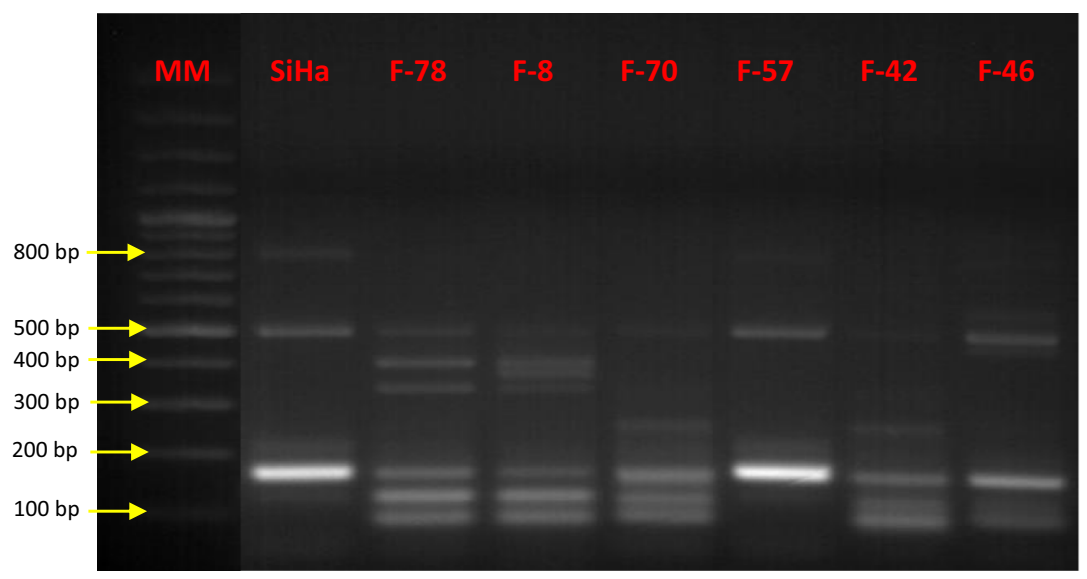

Fig. 1. PCR for second stage selected yeast strains using primers and commercial strain "SiHa".

(Boulton, 1980). Consequently, yeast strain F-46 could be interesting for fermenting grapevines by the lack of acidity. The volatile acidity in all samples was in low amounts from 0.21 to $0.39 \mathrm{~g} / \mathrm{L}$ after the end of malolactic fermentation. That confirmed the purity of the fermentation and the suitable yeast metabolism. Regarding oenochemical parameters of experimental wines, the values of reducing sugars did not exceed $4 \mathrm{~g} / \mathrm{L}$, which indicated the end of alcoholic fermentation (Table 2). The amount of alcohol varied between $11 \%$ and $13 \%$ which correspond to the grapevines initial sugar contents. Values of titratable acidity varied within certain limits without marked tendency. The volatile acidity was in normal range and did not exceed $0.6 \mathrm{~g} / \mathrm{L}$ which means clean fermentation without the participation of harmful yeast or bacterial microflora.

\subsection{The effect of the ten-second stage selected strains on the monomeric anthocyanins and total phenolic compounds in Vranec and Cabernet Sauvignon wines}

The anthocyanin monomers are responsible for the blue-red colors in young red wines (Palomero, Morata, Benito, Calderyn, \& Suárez-Lepe, 2009). The level of the monomeric anthocyanins and total phenolic compounds in Vranec and Cabernet Sauvignon wines are presented in Table 3. The highest level of monomeric anthocyanins $(625 \pm 8 \mathrm{mg} / \mathrm{L})$ was detected in Vranec wine V2 produced by yeast strain $\mathrm{F}-8$. The same wine indicated maximum level of total phenolic compounds $(2896 \pm 5 \mathrm{mg} / \mathrm{L})$. Opposite, the lowest level of monomeric anthocyanins was detected in Vranec wine V11 produced by control yeast $\mathrm{SiHa}(421 \pm 0 \mathrm{mg} / \mathrm{L})$. However, the lowest level of total phenolic compounds was detected in Vranec wine V3 produced by yeast strain F-17. According to Del Barrio-Galán et al. (2015), the higher level of polysaccharide liberation yeast strains can cause interaction with phenolic compounds lowering their level in wines. Regarding Cabernet Sauvignon wines, the wine CS 4 from strain F-20 had the richest source of monomeric anthocyanins $(501 \pm 7 \mathrm{mg} / \mathrm{L})$ and total phenolic compounds $(2720 \pm 12 \mathrm{mg} / \mathrm{L})$. The lowest level of these compounds was detected in wine CS11 produced by control yeast SiHa. This was in agreement with the finding reported by Monagas et al. (2007). According to their findings, anthocyanins were compounds the most affected by the yeast strains in comparison to pyranoanthocyanin and non-anthocyanin phenolic content. The relatively higher amount of monomeric anthocyanins in some wines produced from Vranec grape variety (V2, V7 and V1) in comparison to the same wines produced from Cabernet Sauvignon grape variety can be connected to the dependency of variety. As reported in our previous research (Kostadinović Veličkovska, Mirhosseini, \&
Bogeva, 2013), grape pomace produced from Vranec grape variety had the highest level of monomeric anthocyanins following by grape pomaces from Merlot and Syrah varieties (Kostadinović Veličkovska et al., 2013). Cabernet Sauvignon wine produced by yeast strain F-57 was the second wine with the highest level of monomeric anthocyanins and Vranec wine produced by yeast strain F-46 were wine with the highest level of these compounds after Vranec wines produced by yeast strain F-8.

It makes the impression that in both varieties, the lowest monomeric content was measured in wines produced by control strain $\mathrm{SiHa}$. This finding can be explained by differences in the composition and structure of yeast cell walls. The absorption of the anthocyanins and other phenolic compounds on the cell walls depends on from the polarity of the compounds, their particular structures, and possible steric effects. (Ilieva et al., 2016; Kostadinović et al., 2012; Morata et al., 2016). The comparison of two varieties of wines shows that the yeast strains F-8 and F-20 are able to absorb less amount of pigments in their cell walls than commercial yeast strain SiHa. The findings were in agreement with Settanni et al. (2012), who stated that $S$. cerevisiae strains selected from the indigenous population of the domestic wine-growing area might drive the alcoholic fermentation better than the commercial yeasts.

More precisely, one of our main target was to establish the connection between the clone specifics of the second-stage selected yeast strains and the wines produced by them. The differences in the oenochemical constitution of the wines confirmed the hypothesis that the different DNA-profile leads to different levels of polyphenolic compounds in produced wines. In fact, the character and the properties of the yeasts during alcoholic fermentation have great influence and even determine the character of the produced wine. Our study confirmed, that most of the local strains such F-8, F-20 and F-78 kept and preserved significantly better the specificity of the regional wines from Tikveš region, in comparison to the control strain SiHa. This is more obvious for the local variety Vranec. Consequently, these three yeast strains can be recommended for specific regional wines production. Furthermore, the established similarity in the DNA-profiles of the two couples of the strains (F-57 and the control SiHa; F-42 and F-70) did not lead to similar wines. It can be claimed that the technological conditions also influenced the yeast metabolism, stimulate or inhibit the genetic properties and potential of the cells. Consequently, the quality of the wine is a result of the combination of the genetic properties of the yeast strains and the experimental conditions during wine-making. The results indicated that the genetic properties of the yeast strains had a leading role in wine-making. 


\section{Conclusion}

The current study revealed that the grapevines grown from "Barovo" micro-region were the richest sources of yeast strains. In this study, from 80 newly isolated yeast strains, 10 strains for wine-making were selected. The strains studied in this work maintained an intensive fermentation. The yeast strain F-4 is a strong antagonist to malolactic bacteria. In the samples of wines produced by application of this yeast strain, the malolactic fermentation was not completed. The application of yeast strain F-46 led to produce higher acid content during alcoholic fermentation. This strain could be interesting in the fermentation of grapevines with low acidity. In summary, yeast strains with different DNA-profiles expressed different technological properties. This lays ground to conclude that yeast genotype is equally important as environmental conditions. Finally, the current study recommends yeast strain F-8 and F-78 for the production of wines from Vranec grape variety and yeast strain $\mathrm{F}-20$ production of quality premium wines from Cabernet Sauvignon grape variety.

\section{References}

Aponte, M., \& Blaiotta, G. (2016). Selection of an autochthonous Saccharomyces cerevisiae strain for the vinification of "Moscato di Saracena", a southern Italy (Calabria Region) passito wine. Food Microbiology, 54, 30-39.

Bokulich, N. A., Hwang, C. F., Liu, S., Boundy-Mills, K. L., \& Mills, D. A. (2012) Profiling the yeast communities of wine fermentations using terminal restriction fragment length polymorphism analysis. American Journal of Enology and Viticulture, 63(2), 185-194.

Bokulich, N. A., Thorngate, J. H., Richardson, P. M., \& Mills, D. A. (2014). Microbial biogeography of wine grapes is conditioned by cultivar, vintage, and climate. Proceedings of the National Academy of Sciences of the United States of America, 111(1), 139-148.

Boulton, R. (1980). The relationships between total acidity, titratable acidity and pH in wine. American Journal of Enology and Viticulture, 31(1), 76-80.

Capece, A., Romaniello, R., Siesto, G., Pietrafesa, R., Massari, C., Poeta, C., \& Romano P. (2010). Selection of indigenous Saccharomyces cerevisiae strains for Nero d'Avola wine and evaluation of selected starter implantation in pilot fermentation. International Journal of Food Microbiology, 144, 187-192.

Capece, A., Romaniello, R., Siesto, G., \& Romano, P. (2012). Diversity of Saccharomyces cerevisiae yeasts associated to spontaneously fermenting grapes from an Italian "heroic vine-growing area". Food Microbiology, 31, 159-166.
Del Barrio-Galán, R., Medel-Marabolí, M., \& Peña-Neira, B. (2015). Effect of different aging techniques on the polysaccharide and phenolic composition and sensory characteristics of Syrah red wines fermented using different yeast strains. Food Chemistry, 179, 116-126.

Ilieva, F. Kostadinović Veličkovska, S., Dimovska, V. \& Spasov, H. (2016). The impact of some wine-making practices on the quality of Vranec red wines from Macedonia produced by the newly-selected local strain "F-78". Food Chemistry, 194, 1123-1131.

Kostadinović Veličkovska, S., Mirhosseini, H., \& Bogeva, E. (2013). Isolation of anthocyanins by high-speed countercurrent chromatography and application of colour activity concept to different varieties of red grape pomace from Macedonia. Journal of Nutrition and Food Sciences, 3, 1-7.

Kostadinović, S., Wilkens, A., Stefova, M., Ivanova, V., Vojnoski, B., Mirhosseini, H., \& Winterhalter, P. (2012). Stilbene levels and antioxidant activity of Vranec and Merlot wines from Macedonia: Effect of variety and enological practices. Food Chemistry, 135, 3003-3009.

Legras, J. L., \& Karst, F. (2003). Optimisation of interdelta analysis for Saccharomyces cerevisiae strain characterization. FEMS Microbiology Letters, 221, 249-255.

Mercado, L., Dalcero, A., Masuelli, R. \& Combina, M. (2007). Diversity of Saccharomyces strains on grapes and winery surfaces: Analysis of their contribution to fermentative flora of Malbec wine from Mendoza (Argentina) during two consecutive years. Food Microbiology, 24, 403-412.

Monagas, M., Goméz-Cordovéz, C., \& Bartolomé, B. (2007). Evaluation of different Saccharomyces cerevisiae strains for red winemaking. Influence on the anthocyanin, pyranoanthocyanin and non-anthocyanin phenolic content and colour characteristics of wines. Food Chemistry, 104, 814-823.

Morata, A., Loira, I., Heras, J. M., Callejo, M. J., Tesfaye, W., González, C., \& SuárezLepe, J. A. (2016). Yeast influence on the formation of stable pigments in red winemaking. Food Chemistry, 197, 686-691.

Ness, S. A., Kowenz, L. E., Casini, T., Graf, T., \& Leutz, A. (1993). Myb and NF-M: Combinatorial activators of myeloid genes in heterologous cell types. Genes $\mathcal{E}$ Development, 7, 749-759.

Ortiz, M. J. Barrajón, N., Baffi, M. A., Arévalo-Villena, M., \& Briones, A. (2013) Spontaneous must fermentation: Identification and biotechnological properties of wine yeasts. LWT - Food Science and Technology, 50, 371-377.

Palomero, F., Morata, A., Benito, S., Calderyn, F., \& Suárez-Lepe, J. A. (2009). New genera of yeasts for over-lees aging of red wine. Food Chemistry, 112, 432-441.

Rinaldi, A., Blaiotta, G., Aponte, A., \& Luigi Moio, L. (2016). Effect of yeast strain and some nutritional factors on tannin composition and potential astringency of model wines. Food Microbiology, 53, 128-134.

Settanni, L., Sannino, C., Francesca, N., Guarcello, R., \& Moschetti, G. (2012). Yeast ecology of vineyards within Marsala wine area (western Sicily) in two consecutive vintages and selection of autochthonous Saccharomyces cerevisiae strains. Journal of Bioscience and Bioengineering, 114, 606-614.

Singleton, V. L., \& Rossi, A. Jr., (1965). Colorimetry of total phenolics with phosphomolybdic-phosphotungstic acid reagents. American Journal of Enology and Viticulture, 16(3), 144-158. 